\title{
Electronic Word of Mouth and Purchase Intention on Traveloka
}

\author{
S.A Zahratu* \\ Universitas Pendidikan Indonesia \\ Bandung, Indonesia \\ santyajeng@upi.edu \\ R. Hurriyati \\ School of Postgraduate Studies \\ Universitas Pendidikan Indonesia \\ Bandung, Indonesia
}

\begin{abstract}
Traveling recently became a trend in several countries including Indonesia. The Present of e-commerce in travel industry such as online travel agency (OTA) both local and global have been affecting in communities behavioral and purchasing patterns. Most of Indonesian now tends to use booking online to meet their needs in related to transport, hospitality and tourism. That makes the role of electronic word of mouth (EWOM) also becomes very important for consumer in their online purchasing process. Consumer often to rely on EWOM in review form to collect many information and make purchase decision. The purpose of this study is to examine the influence of EWOM toward consumer purchase intention at Traveloka as one of popular local OTA in Indonesia. The study was conducted by sending directly online questionnaires to $\mathbf{5 0}$ respondents in Bandung city who previously had used online booking services at least once on either Traveloka application or website. This research uses structure equation modeling (SEM) in analyzing data research. The result of this study indi-cates that credibility, quality and quantity of EWOM have negative influence toward intention purchase in Traveloka. From this result Traveloka needs to maintain and improve their consumer satisfaction to consistent-ly learn trust and positive EWOM among consumers to attract intention purchase on other consumer to using them.
\end{abstract}

Keywords-E-Word of Mouth; Online Travel Agency; Purchase Intention

\section{INTRODUCTION}

Traveling recently became a trend in several countries. Based on World Tourism Organization, there are a total of 1322 million international tourist arrivals in 2017 [1]. With almost all activities touched by technology and internet, the importance of communication and technology in tour-ism sector has significantly following to increase [2]. A lot of ecommerce are emerging and growing rapidly along with both that development of digitalization and travel trend in the world. However with the increasing number of Online Travel Agency (OTA) options, customers have to deal with the amount of information that must be faced before their purchase activities [3]. They also have to deal with a lot of product review in various quality and credibility in order to get specific information about the product [4].

The present of e-commerce in traveling industry like travel online agent (OTA) have been affecting communities behavior and consumer purchasing pat-terns. A lot of customers start considering to use a booking online whenever they need anything that re-lated to tourism especially for hospitality and trans-portation. As intangible products that can make them difficult to measured their quality prior from consumer to purchase [5]. From consumers generally always rely on information from word of mouth (WOM) from relative or acquaintance to know attributes and product quality [6]. Nowadays in digital era, consumers are more likely to use WOM through a social media model called electronic word of mouth (EWOM) [7]. Although in a virtual community, consumers can not touch the product or meet EWOM writer to develop trust.

At that time, the role of electronic word of mouth (EWOM) become very important in obtaining information for their purchase decision. Some literatures has identificated that electronic word of mouth (EWOM) significantly influence on consumer puschase intention [8] [9] [10] [11] [12] [13] [14] [15]. Some of the previous study also has examined the influence of EWOM on purchase intention to tourism and hospitality industry [10] to fulfil the gap of the research, this study will examine some of information quality, credibility and Quantity factor related of EWOM adopted from other prior research to identify their influence to purchase intention on OTA.

EWOM is an online form of Word of Mouth (WOM). In addition EWOM is considered an effective way to build awareness in marketing communications [16]. Beside of that to monitoring consumer respond, OTA usually providing their own opinion platform now in their site or application to easier their consumer to search any information. that platformcan helps travelers obtain information and share personal experiences, opinions, photos, hotel reviews and holiday advice [17] For example, Traveloka [18] as a one of leading travel company in Southeast Asia who is providing such as hotel, 
All item has through validity and relability before plane and train ticket and any travel necessary. They have more than two billion trusted online review from hotel guest who will other their user to in make choices [18].

As a result, when consumers read product information, reviews and recommendations, they must depend on their own expertise and engage to determine the credibility of EWOM [12]. Online review (OR) is part of EWOM. As part of it, online consumer reviews help them to determine EWOM credibility and make purchasing decisions. The quantity and quality of online consumer reviews are important characteristics affecting consumer information-processing.

Purchase intention is as consumer intention in purchase a certain product, service or brand [13]. Purchase intentions are formed under the assumption of delayed transactions and, as a result, are often regarded as important indicators of actual purchas [19]. The purchase intention also have been considering as main accurate predictor in actual purchase behavior because they is an important stage of actual purchase [20] [21] [22] which is can give benefit to companies.

This study aim to examine the effect of credibility, quality and quantity of ewom and the factor to purchase intention in OR form on OTA site. There was also some reseach about quality, quantity and credibility of ewom [23] [24]. The dimenstion of ewom quality will adopted from some (relevance, understandability, sufficiency, objective and timeless) [25] [26] This study will also measure EWOM credibility using five dimensions that adopt some research [23] [27] [28] that are expertise, trustworthiness, homophily and aggregated recomendation rating.

H1: EWOM quality positively influence purchasing intention.

H2: EWOM quantity positively influence purchasing intention.

H1: EWOM credibility positively influence purchasing intention.

\section{METHOD}

This research of study has used quantitative method. This research is related of EWOM and purchase in-tention on Traveloka. To examine the study, the re-searchers prepared questionnaire that related to the issue. The questionnaire was created and distributed to Traveloka user directly and through online. The final number of respondent for this research is 50 Traveloka users in Bandung city. The target of this research was customer who previously had used Traveloka at least once through the website or appli-cation.

The questionnaire employs multiple choice questions with regard to variables using the Likert scale with 5 value. To examining EWOM from traveloka user, the data collected and analyzed with Structural Equation Modelling by using SPSS dan AMOS. In process of analysis the data, the researches through EFA (Exploration Factor Analysis) dan CFA (Confirmatory Factor Analysis). Based on the data of respondent was consist of female $(76 \%)$ and male $(24 \%)$. The age majority (59\%) is 17 until 25 years old and for the majority of occupacy (52\%) is company employment. conducted analysis more deeply. In this reseaech all item has been said to be valid and reliable. In validity meansurement that show that rtabel $=0.23$ with $(n)=50$. And for relability measurement show that alpha > rtabel where that means the item was reliabel. The all item analysised by exploration factor analysis (EFA) analysis every item for dimension or variable using SPSS than countinue with confirmation factor analysis (CFA). After all the step the result have to reduce some item. the finally, structural equation model was conducted.

\section{RESUlTS AND DISCUSSION}

The tabel 1 result show that the goodness fit of the researh indexes for the structure model and provides a reasonably good fit for the data degrees of freedom $(\mathrm{df})=38, \mathrm{p}>0.05$; comparative fit index $(\mathrm{CFI})=1.0000$; root mean square error of approximation (RMSEA) $=<0.05$ ). All of these fit indices are acceptable, suggesting that the overall structural model provides a good fit.

\begin{tabular}{|c|c|c|c|c|c|c|}
\hline Model & CMIN & $\begin{array}{c}\text { D } \\
\text { F }\end{array}$ & P & $\begin{array}{c}\text { CMIN } \\
\text { DF }\end{array}$ & CFI & RMSEA \\
\hline $\begin{array}{c}\text { Default } \\
\text { model }\end{array}$ & 33.672 & 38 & 0.6698 & 0.8861 & 1.0000 & 0.0000 \\
\hline $\begin{array}{c}\text { Saturate } \\
\text { model }\end{array}$ & 0.0000 & 0 & & & 1.0000 & 0.2426 \\
\hline $\begin{array}{c}\text { Indepe } \\
\text { ndence }\end{array}$ & 213.61 & 55 & 0.0000 & 3.8839 & 0.000 & \\
\hline Model & & & & & & \\
\hline
\end{tabular}

Another tabel 2 show the hypotesises test of the research. The result show that opposite result the previous result [29] that identified positve effect of EWOM Quality and Quantity to purchase intention. That also opposite of the result of studies that show the significantly impact of one variable or all Credibility, Quantity and quantity EWOM directly to purchase intention [22] [23] [24] [26]. This result rejected all hypothesizes $\mathrm{H} 1-\mathrm{H} 3$ that mean not supported the previous study about ewom quality, credibility and quantity.

Table 2. Regression summary model.

\begin{tabular}{|c|c|c|c|c|c|}
\hline Model & Estimate & S.E. & C.R. & $\mathbf{P}$ & \\
\hline PI $\leftarrow$ Quality & & 2.4821 & 0.9197 & 0.3577 & Rejected \\
\hline \multicolumn{6}{|l|}{ Cont. Table 2.} \\
\hline Model & & S.E. & C.R. & $\mathbf{P}$ & \\
\hline PI $\leftarrow$ Quantity & -1.5822 & 2.3464 & -0.6743 & 0.5001 & \\
\hline $\mathrm{PI} \leftarrow$ Credibility & 0.4910 & 1.2952 & 0.7046 & 0.7046 & Rejected \\
\hline
\end{tabular}

In this study the result do not support the hypothesis. It is probably because the number of the respondents are too small and the focus on online review for this research is only on online review platform at Traveloka site or its application perspective only. Some consumers just come and leave only to collect more information and considering other option from other accommodation and other site. The consumer without planning or wanting to book hotel usually just come for updating information or review. Maybe if this research adding and involving other variable as the reason or motive factors 
from EWOM make a big the difference because the result by reading online review that can make a change in the mouth-tomouth message of the reader to other consumers about the perspective of the product because the belief of online consumer articulation it's the same concept with traditional word of mouth [29].

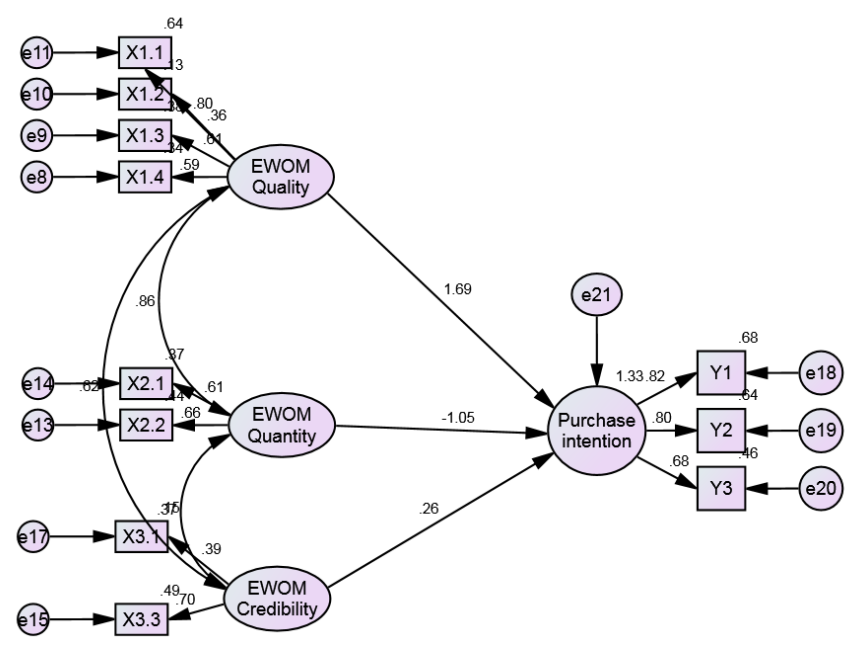

Fig. 1. Final of final SEM analysis.

\section{CONCLUSION}

EWOM have a strong impact in the hospitality industry [30] and tourism industry. It can be really useful for collect lot negative and positive information of the product. Company need to make their review platform more lively not just to give rat-ing and comment but also can be place to discussion. So the credibility, quality and quantity can grow in customer perception toward any information they see in review.

The importance of online review is not only for general online consumer but also for company because online review from user are assisting people in making decisions to buy and improve website usability [31]. EWOM are an important part of the online experience for marketers and consumers [30]. This study limition focus just to review online from the site of an OTA. For the future research, the study about EWOM review can be researcher more deeply.

\section{REFERENCES}

[1] UNWTO. 2018. 2017 International tourism results: The highest in seven years. UNWTO World Tourism Barometer 16: 1-7.

[2] Ariffin, A.S. \& Hashmi, D.P. 2018. Enhancing Malaysian en-trepreneurs business venture and innovation in tourism in-dustry through knowledge and technology adoption. Journal of Science, Technology and Innovation Policy 4(1): 1-12.

[3] Gavilan, D., Avello, M. \& Martinez-Navarro, G. 2018. The in-fluence of online ratings and reviews on hotel booking con-sideration. Tourism Management 66: 53-61.

[4] Cheung, C.M.K. \& Thadani, D.R. 2012. The impact of elec-tronic wordof-mouth communication: A literature analysis and integrative model. Decision Support Systems 54(1): 461-470.

[5] Yang, Y., Park, S. \& Hu, X. 2018. Electronic word of mouth and hotel performance: A meta-analysis. Tourism Man-agement 67: 248-260.
[6] De Maeyer, P. 2012. Impact of online consumer reviews on sales and price strategies: A review and directions for future research. Journal of Product \& Brand Management 21(2): 132-139.

[7] Chakraborty, U. \& Bhat, S. 2018. Effect of credible reviews on brand image: A mixed method approach. IIM Kozhikode Society \& Management Review 7(1): 13-22.

[8] Abubakar, A.M., Ilkan, M. \& Sahin, P. 2016. eWOM, eReferral and gender in the virtual community. Marketing Intelli-gence and Planning 34(5): 692-710.

[9] Alhidari, A., Iyer, P. \& Paswan, A. 2015. Personal level ante-cedents of eWOM and purchase intention, on social net-working sites. Journal of Customer Behaviour 14(2): 107-125.

[10] Kudeshia, C. \& Kumar, A. 2017. Social eWOM: Does it affect the brand attitude and purchase intention of brands?. Management Research Review 40(3): 310-330.

[11] Erkan, I. \& Evans, C. 2016. The influence of eWOM in social media on consumers' purchase intentions: An extended approach to information adoption. Computers in Human Behavior 61: 47-55.

[12] Fan, Y.W. \& Miao, Y.F. 2012. Effect of word-of-mouth on consumer purchase intention: The perspective of gender differences. International Journal of Electronic Business Management 10(3): 175-181.

[13] Farzin, M. \& Fattahi, M. 2018. eWOM through social network-ing sites and impact on purchase intention and brand im-age in Iran. Journal of Advances in Management Research, JAMR 15(2): 161-183.

[14] See-To, E.W.K. \& Ho, K.K.W. 2014. Value co-creation and purchase intention in social network sites: The role of elec-tronic Word-of-Mouth and trust: A theoretical analysis. Computers in Human Behavior 31(1): $182-189$.

[15] Xiao, Z., Zhang, J., Li, D. \& Samutachak, B. 2016. The effect of eWOM on country image and purchase intention: An empirical study on Korean cosmetic products in China. In-ternational Journal of Services Technology and Manage-ment 22(1/2): 18.

[16] Prasetio, A., Sari, P.K. \& Ramadhani, D.P. 2016. Electronic word-ofmouth (EWOM ) adoption model for information security awareness: A case study in university students. Sustainable Collaboration in Business, Technology, Information and Innovation: 154-159.

[17] Kim, S., Kandampully, J. \& Bilgihan, A. 2018. The influence of eWOM communications: An application of online social network framework. Computers in Human Behavior 80: 243-254.

[18] Traveloka. 2018. About traveloka. Retrieved from https://www.traveloka.com/en-id/about-us. Accsessed July 20, 2018

[19] Chang, T.Z. \& Wildt, A.R. 1994. Price, product information, and purchase intention: An empirical study. Journal of the Academy of Marketing Science: Official Publication of the Academy of Marketing Science 22(1): 16-27.

[20] Rahmi, Y., Sekarasih, L. \& Sjabadhyni, B. 2017. The influence of beauty vlog on perceived source credibility and purchase intention. Makara Human Behavior Studies in Asia 21(1): 13.

[21] Reimer, T. \& Benkenstein, M. 2018. Not just for the recom-mender: How eWOM incentives influence the recommen-dation audience. Journal of Business Research, 86: 11-21.

[22] Bataineh, A.Q. 2015. The impact of perceived e-WOM on pur-chase intention: The mediating role of corporate image. In-ternational Journal of Marketing Studies 7(1): 126-137.

[23] Lim, L.M.J. 2016. Analyzing the impact of electronic word of mouth on purchase intention and willingness to pay for tourism related products. Asia Pacific Business \& Econom-ics Perspectives 4(1): 22-50.

[24] Filieri, R. \& McLeay, F. 2014. E-WOM and accommodation: an analysis of the factors that influence travelers' adoption of information from online reviews. Journal of Travel Re-search 53(1): 44-57.

[25] Park, D.H., Lee, J. \& Han, I. 2007. The effect of on-line con-sumer reviews on consumer purchasing intention: The moderating role of involvement. International Journal of Electronic Commerce 11(4): 125148.

[26] Hussain, S., Ahmed, W., Jafar, R.M.S., Rabnawaz, A. \& Jianzhou, Y. 2017. eWOM source credibility, perceived risk and food product customer's information adoption. Com-puters in Human Behavior 66: 96-102. 
[27] Kusumasondjaja, S., Shanka, T. \& Marchegiani, C. 2012. Credibility of online reviews and initial trust: The roles of reviewer's identity and review valence. Journal of Vacation Marketing 18(3) 185-195.

[28] Lin, C., Wu, Y.S. \& Chen, J.C.V. 2013. electronic word-of-mouth: The moderating roles of product involvement and brand image. Proceedings of 2013 International Confer-ence on Technology Innovation and Industrial Manage-ment: 29-47.

[29] Hennig-Thurau, T. \& Walsh, G. 2003. Electronic word-of-mouth: Motives for and consequences of reading customer articulations on the internet. Journal of Electronic Com-merce 8(2): 51-74.
[30] Yan, X., Shah, A.M., Zhai, L., Khan, S., Asad, S. \& Shah, A. 2018. Impact of mobile electronic word of mouth (EWOM) on consumers purchase intentions in the fast-causal restau-rant industry in Indonesia. In Proceedings of the 51st Hawaii International Conference on System Sciences 9: 3801-3810.

[31] Zhao, K., Stylianou, A.C. \& Zheng, Y. 2018. Sources and im-pacts of social influence from online anonymous user re-views. Information and Management 55(1): 16-30. 